\title{
GAMBARAN TINGKAT STRES KELUARGA LANSIA
}

\author{
Mohammad Fatkhul Mubin ${ }^{1}$, Livana PH $^{2}$, Azizah Rahma Mahmudah ${ }^{2}$ \\ ${ }^{1}$ Program Studi Ilmu Keperawatan, Universitas Muhammadiya Semarang \\ ${ }^{2}$ Program Studi Ilmu Keperawatan, STIKES Kendal \\ livana.ph@gmail.com
}

\begin{abstract}
ABSTRAK
Semakin meningkatnya usia harapan hidup penduduk, menyebabkan jumlah lansia terus meningkat dari tahun ketahun. Begitu juga dengan jumlah lansia diseluruh indonesia juga mengalami peningkatan tiap decade. Keluarga merupakan kesatuan dari orang-orang yang terkait dalam perkawinan, hubungan darah, adopsi dan tinggal dalam satu rumah. Adanya kejadian-kejadian yang signifikan seperti anggota keluarga yang mempunyai lansia dalam satu rumah menciptakan kondisi stres bagi keluarga yang merawatnya sehingga menjadi tuntutan yang memaksa keluarga untuk dapat beradaptasi terhadap adanya berubahan dalam segi membagi waktu untuk merawat lansia tersebut. Penelitian ini bertujuan untuk mengetahui gambaran tingkat stres pada keluarga yang mempunyai lansia. Penelitian ini menggunakan metode deskriptif, total sampel 55 responden. Penelitian dilakukan di Desa Mororejo kec. Kaliwungu menggunakan kuesioner Weber State Sniversity dan dianalisis dengan metode deskriptif presentase. Hasil penelitian menunjukkan bahwa sebagian besar keluarga mengalami tingkat stres sedang sebanyak 37 responden (67.27\%) sedangkan tingkat stres berat sebanyak 8 responden (14.55\%) dan tingkat stres ringan sebanyak 10 responden (18.18). Penelitian ini diharapkan keluarga dan lansia untuk lebih memaksimalkan peran sertanya didalam memberikan dukungan kepada keluarga dan lansia guna mengurangi tingkat stres keluarga yang pada akhirnya dapat tercipta kehidupan mental yang lebih sehat baik bagi keluarga maupun lansia dan Sebagai tolak ukur keluarga dalam meningkatkan pengetahuan serta ketrampilan dalam memberi perawatan aktivitas kehidupan sehari-hari.
\end{abstract}

Kata kunci : stres, keluarga lansia

\section{DESCRIPTION OF THE ELDERLY FAMILY STRESS LEVEL}

\begin{abstract}
The family is the unity of the people involved in the marriage, blood relationship, adoption and living in one house. The presence of significant events such as family members who have elderly in a home creates stres for families who care for them so that the demands are forcing the family to be able to adapt to the berubahan in terms of allocating their time to care for the elderly. This study aims to describe the level of stress in families with elderly. This study used a descriptive exploratory method, the total sample of 55 respondents. The study was carried out in the village of Mororejo Kec. Kaliwungu used the Weber State Sniversity questionnaire and analyzed it using descriptive percentage method. The results showed that most families experienced moderate stress levels as much as 37 respondents (67.27\%) while severe stress levels were 8 respondents (14.55\%) and mild stress levels as many as 10 respondents (18.18). This research is expected that families and elderly people to maximize their participation in providing support to families and the elderly to reduce the level of family stress which ultimately can create a healthier mental life for both families and the elderly and as a family benchmark in increasing knowledge and skills in giving daily life care activities.
\end{abstract}

Keywords: Stress, family elderly

\section{PENDAHULUAN}

Semakin meningkatnya usia harapan hidup penduduk, menyebabkan jumlah lansia terus meningkat dari tahun ketahun. Begitu juga dengan jumlah lansia diseluruh indonesia juga mengalami peningkatan tiap dekade pada tahun 2010 sebesar 23,9 juta atau 9,77 persen dari total penduduk dengan usia harapan hidup 67,7 tahun, tahun 2011 sebesar 24 juta jiwa atau hampir 10 persen dan pada tahun 2020 (prakiraan) akan mencapai sebesar 28,28 juta atau 11,34 persen dengan usia harapan hidup 71,1 tahun. Dari total penduduk indonesia, jumlah lansia di pulau jawa tengah sebanyak 11,16 persen dan diperkirakan pada tahun 2020 akan mencapai 29 juta jiwa (Deputi 1 
Menkokesra, 2010). Sedangkan menurut Nugroho (2008) di kota kendal pada tahun 2010 sebanyak 16,5 juta jiwa, diperkirakan pada tahun 2020 jumlah lansia mencapai 28 juta.

Salah satu tolak ukur kemajuan suatu bangsa seringkali dinilai dari angka harapan hidup penduduknya (life expectancy). Indonesia sebagai salah satu Negara berkembang memiliki angka harapan hidup penduduk yang semakin meningkat seiring dengan perbaikan kualitas hidup dan pelayanan kesehatan yang semakin membaik. Namun, di sisi lain meningkatnya angka harapan hidup ini membawa beban bagi masyarakat, karena dengan meningkatnya jumlah penduduk lanjut usia (lansia) meningkat pula rasio ketergantungan lanjut usia (old age dependency ratio). Hal ini menunjukkan bahwa setiap penduduk usia produktif akan menanggung semakin banyak penduduk lanjut usia. Meningkatnya jumlah dan proporsi penduduk lanjut usia dalam struktur kependudukan, tentu akan menimbulkan permasalahan sosial lanjut usia, baik yang akan dirasakan para lanjut usia sendiri maupun berupa beban yang akan dipikul oleh keluarga, masyarakat serta pemerintah. Masalah yang dimaksud adalah kebutuhan yang dirasakan oleh lanjut usia yang merugikan dan mengganggu kemampuan lanjut usia untuk memenuhi kebuuhan riil serta melakasanakan peranan sosialnya.

Bagi Masyarakat Indonesia kebudayaan kekeluargaan sangat kental dan pada umumnya tidak keberatan menerima seseorang jika sudah menjadi tua. Namun kenyataannya banyak keluarga-keluarga yang bahkan mampu dari segi materi tetapi tetap menitipkan orang tuanya ke panti jompo. Sepertinya perlu ditinjau kembali kalau masyarakat Indonesia memiliki rasa kekeluargaan yang kental dan mau menerima anggota keluarga yg lansia. Mungkin hal ini perlu diperjelas sehingga tidak berkepanjangan dan dapat mematahkan mitos kalau lansia itu adalah beban keluarga dan masyarakat, sehingga orang lain dapat memahami lansia secara benar dengan melihat realita yg ada sehingga lansia memiliki hak dan kewajiban yang sama sesuai dengan kondisi, usia, jenis kelamin dan status sosial mereka dalam masyarakat. Pemahamam masyarakat awam tentang lansia dewasa ini masih sangat kurang, tergantung dari tingkat pendidikan, budaya serta hal-hal yang berkaitan dalam aktifitas berinteraksi dalam masyarakat, Tentu hal tersebut juga memberikan andil dalam sudut miring dari kebanyakan masyarakat dalam memandang lansia.

Secara ekonomi, penduduk lanjut usia lebih dipandang sebagai beban dari pada sebagai sumber daya. Banyak orang beranggapan bahwa kehidupan masa tua tidak lagi memberikan banyak manfaat, bahkan ada yang sampai beranggapan bahwa kehidupan masa tua, sering kali dipersepsikan secara negatif sebagai beban keluarga dan masyarakat. Peningkatan jumlah penduduk lanjut usia akan membawa dampak terhadap sosial ekonomi baik dalam keluarga, masyarakat, maupun dalam pemerintah. Implikasi ekonomis yang penting dari peningkatan jumlah penduduk adalah peningkatan dalam ratio ketergantungan usia lanjut (old age ratio dependency). Ketergantungan lanjut usia disebabkan kondisi orang lanjut usia banyak mengalami kemunduran fisik maupun psikis, artinya mereka mengalami perkembangan dalam bentuk perubahan-perubahan yang mengarah pada perubahan yang negatif. Secara umum kondisi fisik seseorang yang telah memasuki masa lanjut usia mengalami penurunansehingga menjadi beban bagi keluarga sehingga waktu keluarga menjadi tersita.

Masalah-masalah yang terjadi pada lansia diantaranya menurunnya fungsi berbagai organ menjadi rentan terhadap penyakit yang bersifat akut atau kronis. Fenomena ini jelas mendatangkan sejumlah konsekuensi, antara lain timbulnya masalah fisik, sosial, serta kebutuhan pelayanan kesehatan dan parawatan, terutama kelainan degenerative atau diabetes mellitus, kecemasan, depresi, gangguan pendengaran, gangguan pada tungkai atau sikap berjalan, gangguan pada koksa atau sendi panggul, anemia (Nugroho, 2008).

Studi pendahuluan di kelurahan Mororejo Kaliwungu terdapat 55 lansia yang sudah berumur lebih dari 60 tahun, dan hidup bersama keluarga atau bersama anaknya dalam satu rumah. Dari 5 sampel terdapat yang diambil terdapat 2 responden yang merasa terbebani dengan adanya lansia, sehingga keluarga terkadang merasa stress karena harus meluangkan waktunya dalam merawat lansia sehingga waktu mereka menjadi tersita, namun 3 responden merasa tidak terbebani. Mereka senang dengan adanya lansia, karena mereka menggap bahwa merawat lansia merup.akan salah satu sikap balas budi. Berdasarkan hasil studi pendahuluan tersebut peneliti tertarik 
melalakukan penelitian dengan judul gambaran tingkat stres pada keluarga yang mempunyai lansia di Desa Mororejo Kaliwungu kabupaten Kendal.

\section{METODE}

Desain penelitian yang digunakan adalah deskriptif. Populasi dalam penelitian ini adalah keluarga yang memiliki lansia yang tinggal dalam satu rumah Dikelurahan Mororejo dan berjumlah 55 Responden. Teknik sampling yang di gunakan dalam penelitian ini adalah sampling jenuh, yaitu dilakukan dengan cara mengambil semua anggota populasi menjadi sampel, sehingga sampel dalam penelitian ini semua keluarga yang merawat lansia berusia lebih dari 60 tahun berjumlah 55 orang dengan kriteria inklusi bahwa keluarga yang merawat lansia tinggal 1 rumah dengan lansia tersebut. analisis data dilakukan untuk mengetahui gambaran tingkat stres pada keluarga yang mempunyai lansia di Kelurahan Mororejo Kecamatan Kaliwungudi analisis dengan menghitung distribusi frekuensinya.

\section{HASIL}

\section{Karakteristik responden}

Hasil penelitian disajikan pada tabel berikut.

Tabel 1.

Distribusi frekuensi responden berdasarkan umur $(\mathrm{n}=55)$.

\begin{tabular}{lrllcccc}
\hline Umur (tahun) & $\mathrm{f}$ & $\%$ & Mean & Median & Modus & Standar deviasi & Nilai Min-Max \\
\hline $31-35$ & 33 & 60 & & & & & \\
\hline $36-40$ & 16 & 29,1 & 35,87 & 34 & 38 & 3,949 & $32-46$ \\
\hline$>41$ & 6 & 10,9 & & & & & \\
\hline
\end{tabular}

Tabel 1 menunjukkan bahwa karakteristik responden berdasarkan usia 31-35 tahun dengan hasil tertinggi sebanyak 33 orang $(60 \%)$, usia $36-40$ tahun dengan hasil 16 orang $(29,1 \%)$, dan hasil terendah pada usia $>41$ tahun sebanyak 6 orang $(10,9 \%)$. Umur responden juga mempunyai nilai rata-rata atau nilai mean 35,87 , nilai median 34 , nilai modus 38 , nilai minimum 32 dan nilai maximum 46. Jadi rata-rata umur responden penelitian di Desa Mororejo kec.Kaliwungu adalah 36 tahun dan sebagaian besar responden berumur 38 tahun.

Tabel 2.

Distribusi frekuensi responden berdasarkan jenis kelamin $(\mathrm{n}=55)$.

\begin{tabular}{lcc}
\hline Jenis Kelamin & $\mathrm{f}$ & $\%$ \\
\hline Laki - Laki & 24 & 43,64 \\
Perempuan & 31 & 56,36 \\
\hline
\end{tabular}

Tabel 2 menggambarkan bahwa karakteristik (56,36\%), dan persentase terendah yaitu lakiresponden berjenis kelamin dengan persentase laki sebanyak 24 orang $(43,64 \%)$.

tertinggi yaitu perempuan sebanyak 31 orang

Tabel 3.

Distribusi frekuensi responden berdasarkan tingkat stres $(\mathrm{n}=55)$.

\begin{tabular}{|c|c|c|c|c|c|c|c|}
\hline Tingkat stress & $\mathrm{f}$ & $\%$ & Mean & Median & Modus & Standar deviasi & Nilai Min-Max \\
\hline Stres ringan & 10 & 18,18 & \multirow{3}{*}{22,34} & \multirow{3}{*}{25} & \multirow{3}{*}{25} & \multirow{3}{*}{5,32019} & \multirow{3}{*}{$11-29$} \\
\hline Stres sedang & 37 & 67,27 & & & & & \\
\hline Stres berat & 8 & 14,55 & & & & & \\
\hline
\end{tabular}

Tabel 3 menunjukan bahwa tingkat stres pada keluarga yang memiliki lansia di Desa Mororejo kec.Kaliwungu dengan hasil persentase tertinggi yaitu stres sedang sebanyak 37 orang $(67,27 \%)$, sedangkan persentase terendah yaitu stres berat sebanyak 8 orang $(14,55 \%)$. Nilai rata-rata atau nilai mean 22 , nilai median 25 , nilai modus 25 , nilai minimum 11 maximum 29. Jadi nilai rata-rata keluarga yang memiliki lansia di Desa Mororejo kec.Kaliwungu memiliki lansia dikatagorikan dalam tingkat stress sedang.

\section{PEMBAHASAN}

\section{Karakteristik responden}

1. Umur

Hasil penelitian menunjukan bahwa mayoritas responden berumur $31-35$ tahun yaitu sebanyak 33 responden $(60 \%)$, responden yang berumur 36 - 40 tahun berjumlah 16 responden $(29,1 \%)$, dan responden yang berumur lebih dari 40 tahun berjumlah 6 responden $(10,9 \%)$. 
dari hasil penelitian di Desa Mororejo kec.Kaliwungu dapat dilihat bahwa rata-rata responden berumur 36 tahun. Menurut Pariani (2000) dalam Notoatmodjo (2003), Umur merupakan indeks yang menempatkan individu - individu dalam urutan perkembangan yaitu usia individu yang terhitung mulai saat dilahirkan sampai saat berulang tahun. Berdasarkan hasil penelitian menunjukan bahwa mayoritas responden berumur 38 tahun sehingga termasuk dalam katagori 36 - 40 tahun.

\section{Jenis Kelamin}

Hasil penelitian menunjukan bahwa mayoritas responden berjenis kelamin perempuan sebanyak 31 responden dalam presentase $(56,36 \%)$ Hal ini dikarenakan pada waktu peneliti melakukan penelitian secara kebetulan yang berada dirumah adalah keluarga lansia yang berjenis kelamin perempuan, sedangkan keluarga lansia yang berjenis kelamin laki-laki kebanyakan sedang bekerja, sehingga didapatkan hasil mayoritas responden berjenis kelamin perempuan.

\section{Gambaran Tingkat Stres keluarga yang memiliki lansia}

Hasil penelitian ini diketahui jumlah tingkat stres yang dialami oleh keluarga lansia sebagian besar mengalami tingkat stres sedang sebanyak 37 orang $(67,27 \%)$, dan jumlah tingkat stres berat sebanyak 8 orang $(14,55 \%)$. sedangkan jumlah tingkat stres ringan 10 orang $(18,18 \%)$. Penjelasan dari hasil penelitian tersebut bahwa sebagian besar keluarga mengalami tingkat stres sedang, karena sebagian besar keluarga merasa terbebani dengan adanya lansia, dimana responden harus membagi waktu untuk keluarganya sendiri dan membagi waktu untuk merawat lansia. Masalah ini sangat membebani responden yang juga bekerja sehingga waktu mereka menjadi tersita, apalagi bagi responden yang memiliki lansia dengan gangguan fisik dalam arti tidak dapat melakukan aktivitas sehari-hari dengan sendiri, sehingga keluarga harus lebih ekstra membagi waktu.

Hasil penelitian ini sesuai dengan teori Hawari, (2008) yang menyatakan bahwa stres adalah respon tubuh yang sifatnya non spesifik terhadap setiap tuntutan beban.Cara individu bereaksi terhadap stres bergantung pada cara mereka memandang dan mengevaluasi dampak dari stresor, dukungan saat mengalami stres serta mekanisme koping mereka. Ketika stres mengganggu mekanisme koping seseorang, maka perilaku seseorang akan mengarah ke maladaptif. Hasil penelitian mayoritas menunjukkan bahwa masalah yang kerap terjadi yaitu responden merasa gugup dan stres, marah karena sesuatu yang terjadi tibatiba, tidak dapat mengatur diri dalam kegiatan harian.

Hal ini merupakan tantangan bagi kita semua untuk dapat mempertahankan kesehatan dan kemandirian para lansia agar tidak menjadi beban bagi dirinya, keluarga maupun masyarakat karena masalah penyakit degenerative akibat proses penuaan yang sering menyertai para lansia. Proses penuaan otak yang merupakan bagian dari proses degenerasi menimbulkan berbagai gangguan neuropsikologis. Salah satu masalah kesehatan yang paling umum terjadi pada kelompok lansia adalah demensia. Tahun 2005 penderita demensia di kawasan Asia Pasifik berjumlah 13,7 juta orang dan diprediksikan pada tahun 2050 jumlah ini akan meningkat menjadi 64,6 juta orang. Berdasarkan data Deklarasi Kyoto, tingkat prevalensi dan insidensi demensia di Indonesia menempati urutan keempat setelah China, India, dan Jepang (Alzheimer's Disease International, 2006).

Demensia merupakan kumpulan gejala klinik yang disebabkan oleh berbagai latar belakang penyakit, ditandai oleh hilangnya memori jangka pendek dan gangguan global fungsi mental, sehingga menimbulkan gangguan dalam aktifitas sehari-hari dan sosial yang disebabkan oleh berbagai keadaan yang bersifat irreversible dan reversible (Yustiani, 2005). Kondisi ini menyebabkan lansia demensia memerlukan perhatian dan perawatan yang khusus dari keluarganya (Miller, 2004). Keluarga memiiiki peran yang sangat penting dalam perawatan lansia demensia di rumah. Perlu persiapan khusus untuk hidup bersama dengan lansia yang mengalami demensia. Persiapan yang dapat dilakukan berupa mental dan lingkungan. Secara mental keluarga harus dapat beradaptasi dengan perubahan yang terjadi pada lansia demensia dan keluarga diharapkan dapat menyediakan lingkungan yang mendukung bagi lansia, yaitu lingkungan yang membuat lansia merasa nyaman. sehingga keluarga khususnya caregiver dapat memberikan perawatan yang optimal bagi lansia. Merawat lansia dengan demensia seyogyanya lebih teliti seperti merawat tubuh, menjaga keamanan dari 
bahaya, memelihara kebersihan dan mengontrol tingkah laku lansia. dan juga merawat jiwa lansia untuk tetap hidup (Touhy, 2005). Merawat lansia demensia penuh dilema bagi keluarga, walaupun setiap han selama hampir 24 jam keluarga merawat lansia, mungkin lansia tidak dapat mengenal dan mengingat siapa keluarga yang merawatnya. Keluarga sebagai caregiver yang tidak memiiiki kesiapan mental sering merasa frustasi dan putus asa karena merasa tidak dapat memberikan yang terbaik untuk orang yang dicintai dan sulit beradaptasi terhadap dampak yang muncul pada keluarga dalam merawat lansia dengan demensia.

Teori lain yang mendukung hasil penelitian ini yaitu, teori Yulianti (2004) yang menyatakan bahwa Respons stres dipakai untuk mendeskripsikan mekanisme yang terlihat dalam respons tubuh untuk bertahan terhadap suatu ancaman fisik. Dalam kondisi stres, tubuh akan mempersiapkan diri untuk melakukan tindakan melawan dan mempertahankan diri sendiri dari ancaman yang menghadang atau lari dan menghindari bahaya yang menghadang. Respons melawan dipicu oleh rasa marah, sebaliknya respons menghindar diawali oleh rasa takut. Secara khusus, kedua respons tubuh tersebut menyebabkan jantung berdebar-debar, pernafasan menjadi cepat, keluar keringat berlebihan, ketegangan otot dan laju metabolik tubuh meningkat.

Tingkat stres lebih banyak di alami oleh perempuan dibandingkan laki-laki di karenakan perempuan lebih cepat stres dan berubah mood (suasana hati) ketimbang lakilaki. Hal ini diperkuat dengan sebuah studi terbaru yang menemukan bahwa kejiwaan perempuan benar-benar dikendalikan oleh hormone Perempuan memang memiliki tingkat depresi, gangguan stres dan masalah kecemasan yang lebih tinggi ketimbang lakilaki. Tapi selama ini belum ada yang mampu menjelaskan perbedaan ini secara biologis. Studi terbaru yang dilakukan di Amerika Serikat dapat membantu menjelaskan perbedaan antara cara laki-laki dan perempuan mengendalikan emosi. Studi ini memfokuskan pada hormon stres yang disebut corticotropinreleasing factor (CRF).

CRF merupakan hormon yang membantu mengontrol reaksi tubuh terhadap stres. Selain itu, CRF juga dikenal memainkan peran dalam kondisi kejiwaan manusia. "Peneliti telah mengetahui bahwa regulasi CRF terganggu pada gangguan jiwa yang berhubungan dengan stres, maka studi ini relevan sebagai alasan biologi, Dr Rita Valentino, dari Rumah Sakit Anak Philadelphia yang memimpin studi, seperti dilansir dari Dailymail, Rabu (16/6/2010). Dr Valentino juga menuturkan bahwa hal ini dapat menjelaskan mengapa perempuan dua kali lipat lebih rentan mengalami gangguan yang berhubungan dengan stres ketimbang laki-laki. Dalam studi yang telah dilaporkan dalam jurnal Molecular Psychiatry ini, diketahui bahwa sel-sel otak perempuan sangat senang dengan dosis CRF yang terlalu rendah bagi laki-laki. Hormon CRF lebih erat terikat pada protein stres sel-sel otak perempuan, sehingga membuatnya lebih sensitif terhadap dampak dari perubahan hormon tersebut. Sedangkan pada laki-laki, otak dapat mengurangi kadar protein, menghentikan hormon dari pengikatan dan mengurangi dampaknya terhadap otak.

Hasil penelitian tingkat stres keluarga di Desa Mororejo kec.Kaliwungu sebagian besar mengalami stres sedang $(67,27 \%)$. Tanda dan gejala stres yang sering responden alami saat merawat lansia adalah jantung berdebar-debar, sering pusing, keluar keringat yang berlebihan, perasaan ingin marah karena ketidakmampuan mengatasi masalah lansia tersebut, sehingga responden mengabaikan masalah yang dihadapi dan lebih memfokuskan hal lain yang tidak berhubungan dengan lansia. Hal ini akan mempersempit lahan persepsi responden dalam merawat lansia. Faktor kesibukan bekerja sangat mempengaruhi karna kesibukan responden hampir menyita seluruh waktunya, faktor perubahan tingkah laku karena sikap dan tingkah laku lansia yang seperti kekanakkanakan, faktor kurang mandiri karena dalam melakukan semua aktifitas lansia memerlukan bantuan sehingga responden merasa direpotkan dan faktor perekonomian rendah cukup mempenngaruhi karena pendapatan yang rendah akan mengalmi kesulitan untuk memenuhi kebutuhan sehingga menimbulkan stres bagi keluarga.

\section{SIMPULAN DAN SARAN}

\section{Simpulan}

Berdasarkan hasil penelitian yang telah dilakukan mengenai "Gambaran tingkat stres pada keluarga yang memiliki lansia di Desa Mororejo kec.Kaliwungu, maka dapat disimpulkan sebagai berikut : 
1. Gambaran tingkat stres pada keluarga yang memiliki lansia di Desa Mororejo kec.Kaliwungu sebagian besar adalah responden yang berumur 31 - 35 sebanyak 33 responden $(60 \%)$.

2. Gambaran tingkat stres pada keluarga yang memiliki lansia berdasarkan jenis kelamin di Desa Mororejo kec.Kaliwungu sebagian besar adalah perempuan sebanyak 31 responden $(56,36 \%)$.

3. Gambaran tingkat stres pada keluarga yang memiliki lansia mayoritas mengalami stres sedang sebanyak 37 orang $(67,27 \%)$

\section{Saran}

Hasil penelitian ini diharapkan dapat menambah pengetahuan dan wawasan peneliti tentang gambaran tingkat stres keluarga yang memiliki lansia

\section{DAFTAR PUSTAKA}

Deputi I Menkokesra (2010), Data jumlah lansia di Indonesia.

Depkes RI (1998) di kutib dalam buku konsep dan proses keperawatan keluarga, Setiadi(2010).

Potter (2005), Pengertian stress terhadap keluarga http//www,stress.net/makalah di akses pada tanggal 24 September 2012.

Friedman (1998), Keperawatan keluarga teori dan praktik. Edisi 3. Jakarta : Penerbit Buku Kedokteran EGC.

Nugroho, Wahyudi, SKM. 2000. Keperawatn Gerontik Edisi 2. Jakarta : EGC

Suryanto (2004), Optimalisai Peran dan Fungsi Keluarga.

Hawari (2004), http//www.stres.net di akses pada tanggal 25 September 2012.

Junaidi (2008), Penduduk Lanjut Usia dan Peranan Keluarga.

Louw Anneke (2009), Stres psikologi keluarga http//www.psikologi.net di akses pada tanggal 24 September 2012.

Pranowo, Hadi (2004) http//www.Sumber stress.net di akses pada tanggal 25 September 2012.
Psychology Foundation Of Australia. (2010). Depression Anxiety Sress Scale.

Http://Www2.Psy.Unsw.Edu.Au/Group/Dass.

Stuart, G.W \& Laraia, M.T (2005). Psychiatric nursing : Principle and practice 8th Edition. St. Louis : Mosby.

Suarez K, Mayer C, Ehlert U, Nater UM: Psychological stress and selfreported functional gastrointestinal disorders. J Nerv Ment Dis 2010, 198:226-9.

Sukmawati, Astri. (2015). Hubungan antara Kecerdasan dengan Tingkat Stres Mahasiswa FIK UI (Skripsi). Universitas Indonesia, Depok, Jawa Barat.

Suzanne \& Brenda. (2008). Text book of medical surgical nursing 11th ed. Philadelphia: Lippincott Williams \& Wilkins

Stock C, Kucuk N, Miseviciene I, GuillenGrima F, Petkeviciene J, AguinagaOntoso I, Kramer A. (2003). Differences in health complaints among university students from three European countries. Prev Med 2003, 37:535-43.

Wilks, S.E. (2008). Resilience amid academic stress: The moderating impact of social support among social work student: advances in social work, 9 (2), 106125.

https://journals.iupui.edu/indeks.php/ad vancesinsocialwork/article/viewFile/51/ $\underline{195}$ 